\title{
CHARACTERIZATION OF SOME PRODUCTIVE AND REPRODUCTIVE TRAITS OF SYRIAN SHAMI AND HOLSTEIN COWS UNDER SYRIAN CONDITIONS
}

\author{
O. Almasri ${ }^{1}$, S. Abou-Bakr ${ }^{2}$ and M. A. M. Ibrahim ${ }^{2}$ \\ 1- General Commission for Scientific Agricultural Research, Damascus, Syria, 2- Department of Animal \\ production, Faculty of Agriculture, University of Cairo, Giza, Egypt. \\ Corresponding author: obaidaalimasri@gmail.com
}

Received: 13/1/2021 Accepted: 10/2/2021

\section{SUMMARY}

The objective of this study was to evaluate the productive and reproductive performances of Shami and Holstein cows under the Syrian conditions. In this study, 2654 and 4289 records were collected on 569 Shami and 1669 Holstein cows, respectively during the period from 1978 to 2015 of two experimental stations, Ministry of Agriculture and Land Reclamation, Syria. Data were analyzed using the General Linear Model (XLSTATE. 2020). Age at first calving (AFC), calving interval (CI), total milk yield (TMY), daily milk yield $(D M Y)$, and lactation period $(L P)$ were significantly affected $(p<0.01)$ by the breed. The least-square means for AFC, CI, TMY, DMY, and LP were $31 \pm 0.14$ months, $442 \pm 2.83$ days, $1587 \pm 34.89 \mathrm{~kg}, 9.1 \pm 0.09 \mathrm{~kg}$ and $165 \pm 2.0$ days in Shami breed, respectively, compared to $28.1 \pm 0.10$ months, $432 \pm 3.34$ days, $5494 \pm 41.21 \mathrm{~kg}, 16.7 \pm 0.11 \mathrm{~kg}$ and $332 \pm 2.36$ days in Holstein breed, respectively, under Syrian conditions. The present study revealed that Shami cows performed less estimates in all studied traits compared to the Holstein cows under the Syrian conditions. Successful management and genetic improvement for Shami cows could enhance their productive and reproductive performances.

Keywords: Productive, Reproductive, Syrian Shami, Holstein

\section{INTRODUCTION}

The improvement of Animal production performance depends on the genetic structure of the animal. Providing the proper feeding, appropriate management and adequate veterinary services allow the animal to express its genetic potential and consequently obtain the highest yield. While unfavorable environmental conditions cause decreasing in the productive and reproductive performance of farm animals (Ansell, 1981).

Local breeds are characterized by less efficiency and late maturity compared to the Holstein cows. But it is necessary to maintain and conserve the local breeds because those breeds can tolerate the harsh environmental conditions for a lot of hundreds of years. sides, Holstein cows suffer lacking adaptability in unfavorable environmental conditions (RojasDowning et al., 2017).

Age at first calving (AFC) reflects the growth rate of heifers. Reducing AFC contributes to genetic progress by reducing the generation interval (Pirlo et al., 2000). Decreasing AFC can provide a lot of anumber of calving and milk production from cows during their lifespan and reduces high replacement costs. The typical AFC should be around 24 months (Sawa et al, 2019).

Delayed AFC raises the rearing costs and reduces total milk yield during productive life and leads to a loss of the income of dairy farms. The main reason for delayed the AFC is inappropriate feeding for heifers that causes late sexual maturity (Duplessis et al. 2015).
Calving interval (CI) is a crucial factor in determining the reproductive performance and income of dairy production (Alemayehu and Moges, 2014). Typical CI results in an increased number of calvings and reduces drying off periods that lead to getting more milk produced from cows during their productive life. Most authors reported that the optimum CI ranges between 365-380 days (Azizunnesa, 2002). Calving interval has low heritability, so it can be reduced through feeding and successful management. Milk production level and persistence are important factors for determining the proper calving interval (Mukasa-Mugerwa et al., 1991).

The lactation period of dairy cows contributes to determining the total milk production, daily milk yield, and persistence. The standard lactation period should be around 305 days. Generally, local cows have a short lactation period compared to Holstein cows (Mulugeta and Belayneh, 2013).

The present study was designed to characterize some the productive and reproductive performances of Syrian local Shami and Holstein breeds under the Syrian conditions.

\section{MATERIALS AND METHODS}

Data:

Data used in the present study were collected from two farms under Syrian conditions and covered 38 years (1978-2015). The first farm contains 2654 records for 569 Syrian local Shami cows belonging to the Deir al-Hajar station. The second farm contains 
4289 records for 1669 Holstein cows belonging to the Fedio dairy station.

\section{Herd management:}

Animals in the two farms were reared under a free housing system in semi-closed sheds. Feeds were offered twice a day. Water was available. In the first farm (Shami), heifers were naturally inseminated for the first time when they reach the age of 18 months taking into account the weight of the heifer. In the second farm (Holstein), heifers were artificially inseminated when they reach the age of 13-15 months taking into account the weight of the heifer. All cows in the two farms were machine milked twice a day at 06.00 a.m. and 6.00 p.m.

\section{Studied traits:}

\section{a- Productive traits:}

1-Total Milk Yield (TMY, kg): milk production through lactation period.

2- Daily Milk Yield (DMY, kg): total milk yield /lactation period.

3- Lactation Period (LP, days): number of days in milk, from calving date to dry off date.

\section{b- Reproductive traits:}

1- Age at First Calving (AFC, month): The number of days between date of birth and date of the first calving of a cow divided by 30.5 .

2- Calving Interval (CI, days): The period of time elapsed between two consecutive parturitions.

\section{Statistical analysis:}

Data were subjected to statistical analysis of variance as repeated measurements, using the General Linear Model of (XLSTAT 2020.3.1.27 program). The effect of farm is not included in the following statistical model, because each farm contains one breed only. The two statistical models used were as follows:

The first model for age at first calving trait:

$\mathrm{Y}_{\mathrm{ijkl}}=\mu+\mathrm{B}_{\mathrm{i}}+\mathrm{Y}_{\mathrm{j}}+\mathrm{S}_{\mathrm{k}}+\mathrm{e}_{\mathrm{ijkl}}$

Where:

$\mathrm{Y}_{\mathrm{ijk}}=$ the observation of age at first calving trait,

$\mu=$ the overall mean,
$B_{i}=$ the fixed effect of $i^{\text {th }}$ breed $(i=1,2$,), where $1=$ Syrian Shami cows, and $2=$ Holstein cows,

$\mathrm{Y}_{\mathrm{j}}=$ the fixed effect of $\mathrm{j}^{\text {th }}$ year of $\operatorname{birth}(\mathrm{j}=1,2,3)$, where $1=1978-1989,2=1990-2001$, and $3=2002-2013$,

$\mathrm{S}_{\mathrm{k}}=$ the fixed effect of $\mathrm{k}^{\text {th }}$ season of $\operatorname{birth}(\mathrm{k}=1,2,3,4)$, where $1=$ winter, $2=$ spring, $3=$ summer and $4=$ autumn, and

$\mathrm{e}_{\mathrm{ijk}}=$ the random error assumed N I D $\left(0, \sigma^{2} \mathrm{e}\right)$

The second model for the other studied traits:

$\mathrm{Y}_{\mathrm{ijklm}}=\mu+\mathrm{B}_{\mathrm{i}}+\mathrm{Y}_{\mathrm{j}}+\mathrm{S}_{\mathrm{k}}+\mathrm{P}_{1}+(\mathrm{B} \times \mathrm{P})_{\mathrm{il}}+\mathrm{e}_{\mathrm{ijklm}}$

Where:

$\mathrm{Y}_{\mathrm{ijklm}}=$ the observations of productive and reproductive traits,

$\mu=$ the overall mean,

$\mathrm{B}_{\mathrm{i}}=$ the fixed effect of $\mathrm{i}^{\text {th }}$ breed $(\mathrm{i}=1,2$,), where $1=$ Syrian Shami cows, and $2=$ Holstein cows,

$Y_{j}=$ the fixed effect of $j^{\text {th }}$ year of calving $(j=1,2,3)$, where $1=1980-1991,2=1992-2003$, and $3=2004-$ 2015 ,

$\mathrm{S}_{\mathrm{k}}=$ the fixed effect of $\mathrm{k}^{\text {th }}$ season of calving $(\mathrm{k}=1,2,3$, 4), where $1=$ winter, $2=$ spring, $3=$ summer and $4=$ autumn,

$\mathrm{P}_{1}=$ the fixed effect of $1^{\text {th }}$ parity, where $(1=1,2,3,4, \geq$ 5),

$(\mathrm{B} \times \mathrm{P})_{\mathrm{il}}=$ the effect of the interaction between $\mathrm{i}^{\text {th }}$ breed and $1^{\text {th }}$ parity, and

$\mathrm{e}_{\mathrm{ijklm}}=$ the random error assumed N I D $\left(0, \sigma^{2} \mathrm{e}\right)$.

\section{RESULTS AND DISCUSSION}

\section{a- Productive traits:}

The results in this study showed that the breed and year of calving affected significantly all studied productive traits. While the season of calving had no significant on all studied productive traits. The effect of parity was highly significant on total milk yield (TMY) and daily milk yield (DMY). The interaction between breed and parity had a significant effect on the lactation period only (Table 1). These results in the current study agree with those of Toure et al (2019) in Mali, Basak and Das (2018) in India and Abera (2016) in Ethiopia.

Table 1. Level of significance $(p<)$ of the factors affecting the productive traits

\begin{tabular}{lccc}
\hline Source of variation & \multicolumn{3}{c}{$\mathrm{P}<$} \\
\cline { 2 - 4 } & Total milk yield $(\mathrm{kg})$ & Daily milk yield $(\mathrm{kg})$ & Lactation period (day) \\
\hline Breed & 0.0001 & 0.0001 & 0.0001 \\
Year of calving & 0.0001 & 0.0001 & 0.0001 \\
Season of calving & 0.169 & 0.452 & 0.122 \\
Parity & 0.0001 & 0.0001 & 0.808 \\
Interaction between breed and & 0.287 & 0.0084 & 0.0005 \\
parity & & & \\
\hline
\end{tabular}

1- Least-square means of the studied productive traits as affected by breed:

The total milk yield (TMY) of Holstein cows $(5494 \mathrm{~kg})$ was significantly higher than that of Syrian Shami cows $(1587 \mathrm{~kg})$ as shown in Table 2. It could be mainly attributed to the difference in genetic potential between the two breeds, management practices, and feeding system in the two farms. These results were in accordance with those of Mekonnen and Selam (2020) who reported that the effect of breed on total milk yield was clear enough, they found the TMY was $3311 \mathrm{~kg}$ of Holstein cows compared to 
$771 \mathrm{~kg}$ in purebred cows under Ethiopia conditions. Likewise, Ali et al (2019) found that milk production was higher in Holstein Friesian (2678 kg) compared to $(594.4 \mathrm{~kg})$ of Achai cows in Pakistan. Also, Ghoneim et al (2018) reported that the total milk yield in Holstein Friesian was $(7024.41 \mathrm{~kg})$ higher than that $(2761.47 \mathrm{~kg})$ in local cows in Egypt, they attributed the difference in milk production among breeds to difference in udder conformation scores and milking characteristics among breeds (Busato et al., 2000).

The above results can confirm the highly significant effect of breed on total milk yield in different countries.

Daily milk yield (DMY) in the present study of Holstein cows $(16.7 \mathrm{~kg})$ was and highly significantly greater than that of Shami cows $(9.1 \mathrm{~kg})$. It may be attributed to the total difference in genetic structure between the breeds. This result was in agreement with that of Toure et al. (2019) who found that the DMY was $5.13 \mathrm{~kg}$ of Holstein crossbred compared to 3.17 and $3.05 \mathrm{~kg}$ in local Azawak zebu and local Peul and Maure, respectively, in Mali. Also, Manzi et al (2020) reported that the local pure Ankole cows had a lower daily milk yield $(1.8 \mathrm{~kg})$ compared to $4.6 \mathrm{~kg}$ in the crossbreds (Ankole $\times$ Friesian) in Rwanda. Tadesse and Dessie (2003) reported that the Holstein Friesian breed produced daily milk yield $(9.43 \mathrm{~kg})$ higher than the local Barca breed $(2.98 \mathrm{~kg})$ in Ethiopia. Mamun et al (2015) found that the daily milk yield was higher in the Holstein Friesian crossbred (7.64 L) compared to $(1.75 \mathrm{~L})$ in local cows in Bangladesh. Ghoneim et al (2018) reported that the daily milk yield in Holstein Friesian was $(20.78 \mathrm{~kg})$ higher than that $(10.97 \mathrm{~kg})$ in local cows in Egypt.

The Holstein breed in the current study had a lactation period (332 days) longer than Shami cows (165 days) (Table 2). This is mainly attributed to the genetic structure of breed and also milk yield in Holstein cows was higher than Shami cows. Sides, Holstein breed had high persistency compared to the Shami breed. This result was similar to Mekonnen and Selam (2020) who observed that local cows had a shorter lactation period (198) days than that of Holstein cows (335 days) under Ethiopia conditions. Hermiz and Hadad (2020) reported that the Simmental had a higher lactation period (302.95 days) comparing with Friesian (296.81 days) and Bokane (293.24 days) under Iraqi conditions. Tadesse and Dessie (2003) reported that the Holstein Friesian breed had a lactation period (362 days) longer than the local Barca breed (279 days) in Ethiopia. Ghoneim et al. (2018) reported that the lactation period in Holstein Friesian was (347.63 days) longer than (254.83 days) in local cows in Egypt.

Table 2.Least-square means and standard error $(\mathrm{LSM} \pm \mathrm{SE})$ for studied productive traits as affected by breed, year and season of calving and parity

\begin{tabular}{|c|c|c|c|}
\hline Source of variation & Total milk yield (kg) & Daily milk yield (kg) & Lactation period (day) \\
\hline \multicolumn{4}{|l|}{ Breed } \\
\hline Shami & $1587^{\mathrm{a}} \pm 34.89$ & $9.1^{\mathrm{a}} \pm 0.09$ & $165^{\mathrm{a}} \pm 2.0$ \\
\hline Holstein & $5494^{\mathrm{b}} \pm 41.21$ & $16.7^{\mathrm{b}} \pm 0.11$ & $332^{\mathrm{b}} \pm 2.36$ \\
\hline \multicolumn{4}{|l|}{ Year of calving } \\
\hline $1980-1991$ & $3478^{\mathrm{b}} \pm 57.53$ & $13.2^{\mathrm{b}} \pm 0.15$ & $242^{\mathrm{a}} \pm 3.29$ \\
\hline $1992-2003$ & $3329^{a} \pm 33.10$ & $11.8^{\mathrm{a}} \pm 0.08$ & $258^{\mathrm{b}} \pm 1.89$ \\
\hline 2004-2015 & $3814^{c} \pm 38.65$ & $13.8^{\mathrm{c}} \pm 0.10$ & $246^{\mathrm{a}} \pm 2.21$ \\
\hline \multicolumn{4}{|l|}{ Season of calving } \\
\hline Winter & $3515^{\mathrm{a}} \pm 44.18$ & $12.9^{\mathrm{a}} \pm 0.11$ & $245^{\mathrm{a}} \pm 2.53$ \\
\hline Spring & $3564^{\mathrm{a}} \pm 49.60$ & $13.0^{\mathrm{a}} \pm 0.13$ & $251^{\mathrm{a}} \pm 2.84$ \\
\hline Summer & $3478^{\mathrm{a}} \pm 47.91$ & $12.8^{\mathrm{a}} \pm 0.12$ & $247^{\mathrm{a}} \pm 2.74$ \\
\hline Autumn & $3604^{\mathrm{a}} \pm 44.34$ & $13.0^{\mathrm{a}} \pm 0.11$ & $252^{\mathrm{a}} \pm 2.54$ \\
\hline \multicolumn{4}{|l|}{ Parity } \\
\hline 1 & $3160^{\mathrm{a}} \pm 37.37$ & $11.3^{\mathrm{a}} \pm 0.10$ & $249^{\mathrm{a}} \pm 2.14$ \\
\hline 2 & $3513^{\mathrm{b}} \pm 44.36$ & $12.7^{\mathrm{b}} \pm 0.11$ & $251^{\mathrm{a}} \pm 2.54$ \\
\hline 3 & $3635^{\mathrm{bc}} \pm 54.57$ & $13.4^{\mathrm{c}} \pm 0.14$ & $250^{\mathrm{a}} \pm 3.12$ \\
\hline 4 & $3746^{\mathrm{c}} \pm 70.90$ & $13.7^{\mathrm{c}} \pm 0.18$ & $249^{\mathrm{a}} \pm 4.06$ \\
\hline$\geq 5$ & $3648^{b c} \pm 73.0$ & $13.5^{\mathrm{c}} \pm 0.19$ & $245^{\mathrm{a}} \pm 4.18$ \\
\hline
\end{tabular}

Means followed by different superscripts are significantly different $(\mathrm{p}<0.05)$, Means followed by same superscripts are not significantly different.

2-Least-square means of the studied productive traits as affected by year and season of calving:

The effect of year of calving on all studied productive traits was significant as shown in Table (1). The differences in studied traits between periods could be attributed to variations in management conditions, climate, and feed quality and system. Similar results to the present study were also reported by Manzi et al (2020) of cows in Rwanda. On the contrary, Chaudhary et al (1996) found that year of calving was no significant effect on the daily milk yield of the Holstein Friesian cows in Pakistan.

The effect of season of calving on TMY, DMY, and LP was non-significant (Table 2). These findings agree with those of Bayou et al (2015) on Sheko cattle in Ethiopia. On the contrary, Ayeneshet et al (2018) showed that the highest DMY occurred(2 and $1.75 \mathrm{~L})$ during Jun-Aug and Sep-Nov respectively, and the 
lowest $(0.73$ and $0.28 \mathrm{~L})$ during Dec-Feb and MarMay, respectively, on local dairy cows in Ethiopia. Cilek and Bakir (2010) observed that the LP was prolonged in cows calved in winter, due to increased milk production combined with the availability of quality feed in Brown Swiss cows in Turkey.

\section{3-Least-square means of the studied productive traits as affected by parity:}

The results showed that there was an increase in the TMY and DMY with the progress of the parity and up to the fourth parity (3746 and $13.7 \mathrm{~kg}$, respectively), then decreased after that (Table 2). This could be due to increase the capacity of feed intake compared to the cows of the first parity, and full development of the mammary glands, which led to an increased of the TMY and DMY. While decreased TMY and DMY after the fourth parity might be due to increased mortality of secretory cells with advancement of age. Likewise, Manzi et al (2020) reported that the cows in the fourth parity produced highest milk yield and the lowest was that of the first party in Rwanda. On the other hand, Bahashwan (2020) found that the effect of parity on TMY was nonsignificant. Chaudhary et al
(1996) reported that no significant effect for the parity on the daily milk yield in the Holstein Friesian cows in Pakistan.

The effect of Parity was nonsignificant in the lactation period (Table 2). Similar results were observed by Kumar et al (2003) in Ongole cattle. Conversely, Basak and Das (2018) indicated the shortest LP was in the first parity compared to other parities on Deoni cows in India. Hermiz and Hadad (2020) found that LP was reduced significantly from 306 days in the first parity to 290 days in the fourth parity in Iraq. While Cilek (2009) found the LP was longest in first parity (315 days) and shortest in fifth parity (285 days) of Holstein cows in Turkey.

\section{b- Reproductive traits: \\ 1- Age at first calving (AFC):}

The results in this study showed that breed had a significant effect on age at first calving, but the effect of year and season of birth was nonsignificant on age at first calving (Table 3). These results are in agreement with those of Abera (2016) in Ethiopia and Ardicli et al. (2019) in Turkey.

Table 3. Level of Significance $(p<$ ) of the factors affecting age at first calving AFC

\begin{tabular}{lc}
\hline Source of variation & $\mathbf{p}<$ \\
\hline Breed & $\mathbf{0 . 0 0 0 1}$ \\
Year of birth & 0.241 \\
Season of birth & 0.154 \\
\hline
\end{tabular}

a-Least-square means of the age at first calving (AFC) as affected by breed:

The difference between the least-square means in the two breeds under this study for age at first calving was highly significant. The lowest age at first calving was observed in Holstein cows $28.1 \pm 0.10$ months and the highest was in Shami cows $31.0 \pm 0.14$ months (Table 4). This might be attributed to reduced growth rate and delayed sexual maturity due to the low level of feeding in Shami heifers. The results of this study agreed with the findings of Mulugeta and Belayeneh (2013) who reported that the AFC was 47.16 \pm 8.7months for local cows compared to $37.95 \pm 9.4$ months for crossbreed cows in Ethiopia, and they explained the variation in AFC between local breed and crossbreed was probably due to difference in genetic potential and difference in management policy and nutrition conditions. Hermiz and Hadad (2020) reported that the Friesian breed had a shorter AFC (27.301 mo.) than Bokane cows (28.6 mo.) in Iraq.

Mamun et al (2015) found that the AFC was lower in the Holstein Friesian crossbred (36.43 months) compared to (40.07 months) in local cows in Bangladesh. Whereas, Ali et al (2019) found that the AFC was longer in Holstein Friesian (34 months) compared to (32.6 months) in Achai cows in Pakistan.

Table 4. Least-square means and standard error ( $\mathrm{LSM} \pm \mathrm{SE}$ ) of age at first calving as affected by breed

\begin{tabular}{lc}
\hline Source of variation & LSM \pm SE \\
\hline Breed & $* *$ \\
Shami & $31.0^{\mathrm{b}} \pm 0.14$ \\
Holstein & $28.1^{\mathrm{a}} \pm 0.10$ \\
\hline$*(\mathrm{p}<0.01)$, Means followed by different superscripts are significantly different $(\mathrm{p}<0.05)$
\end{tabular}

\section{b-Least-square means of the age at first calving} (AFC) as affected by year and season of birth:

The results in Table (5) showed that there is no significant effect for the year of birth on age at first calving. This result agreed with that of Sadek et al. (1994) on Friesian cows in Egypt. On the other hand, Kumar et al (2015) found a significant effect for the year of birth on Frieswal cattle in India. They referred it due to changes in feeding, managerial systems that practiced from one year to another.
Also, the current results indicated that the effect of season of birth on age at first calving was not significant (Table 5). This result is in accordance with Sattar et al. (2005) of Friesian cows in Pakistan. Otherwise, Almasri (2010) found that the lowest age at the first calving was in autumn (28.36 months) and the highest in the spring (29.85 months) on Holstein Friesian cows in Syria, the author attributed that to differences in climatic conditions and feeding types during those seasons. 
Table 5. Least-square means and standard error $(\mathrm{LSM} \pm \mathrm{SE})$ of age at first calving as affected by year and season of birth

\begin{tabular}{cc}
\hline Source of variation & LSM \pm SE \\
\hline Year of birth & NS \\
$1978-1989$ & $29.3 \pm 0.18$ \\
$1990-2001$ & $29.6 \pm 0.13$ \\
$2002-2013$ & $29.7 \pm 0.13$ \\
Season of birth & NS \\
Winter & $29.8 \pm 0.16$ \\
Spring & $29.6 \pm 0.17$ \\
Summer & $29.3 \pm 0.16$ \\
Autumn & $29.6 \pm 0.16$ \\
\hline
\end{tabular}

NS = not significant.

\section{2- Calving interval (CI):}

The present study showed that the breed, season of calving, and interaction between breed and parity affected significantly calving interval. While the year of calving and parity had a highly significant effect on calving interval (Table 6). These results agreed with those of Wondossen et al. (2018) in Ethiopia.

Table 6.Level of significance $(p<)$ of the factors affecting calving interval

\begin{tabular}{lc}
\hline Source of variation & $\mathbf{p}<$ \\
\hline Breed & $\mathbf{0 . 0 1 5}$ \\
Year of calving & $\mathbf{0 . 0 0 0 1}$ \\
Season of calving & 0.05 \\
Parity & $\mathbf{0 . 0 0 1}$ \\
Interaction between breed and parity & $\mathbf{0 . 0 2 8}$ \\
\hline
\end{tabular}

a-Least-square means of the calving interval (CI) as affected by breed:

Table (7) showed that the Holstein breed had a shorter calving interval (432 days) than the Shami breed (442 days). This result was correspondent with Cherkoes and Mekuria (2018) who found that the CI was lower significantly in crossbreds (525 days) compared to the local breed (611.9 days) in Ethiopia, and they explained that this difference could be attributed to the variations of management policy (feeding, heat detection, and housing) between the two breeds and farmers gave special attention to crossbred cows. On the other hand, Saleem et al. (2012) found the CI was longer in Holstein Friesian (567.8 days) compared to (464 days ) in the Sahiwal breed in Pakistan. The lower reproductive traits in the Holstein breed could be due to the high milk production for Holstein cows which led to reducing reproductive efficiency compared to local breed or crossbreed, since there is a negative correlation between productive and reproductive traits.

Table 7.Least-square means and standard error (LSM $\pm \mathrm{SE})$ of calving interval as affected by breed, year and season of calving and parity

\begin{tabular}{lc}
\hline Source of variation & Calving interval (day) \\
\hline Breed & $* *$ \\
Shami & $442^{\mathrm{b}} \pm 2.83$ \\
Holstein & $432^{\mathrm{a}} \pm 3.34$ \\
Year of calving & $* *$ \\
$1980-1991$ & $456^{\mathrm{b}} \pm 4.67$ \\
$1992-2003$ & $431^{\mathrm{a}} \pm 2.69$ \\
$2004-2015$ & $425^{\mathrm{a}} \pm 3.14$ \\
Season of calving & $* *$ \\
Winter & $437^{\mathrm{ab}} \pm 3.59$ \\
Spring & $444^{\mathrm{b}} \pm 4.02$ \\
Summer & $438^{\mathrm{ab}} \pm 3.8 \alpha 9$ \\
Autumn & $430^{\mathrm{a}} \pm 3.60$ \\
Parity & $* *$ \\
1 & $450^{\mathrm{c}} \pm 3.03$ \\
2 & $441^{\mathrm{bc}} \pm 3.60$ \\
3 & $434^{\mathrm{ab}} \pm 4.43$ \\
4 & $427^{\mathrm{a}} \pm 5.75$ \\
$\geq 5$ & $435^{\mathrm{ab}} \pm 5.92$ \\
\hline
\end{tabular}

$* *(\mathrm{p}<0.01)$, Means followed by different superscripts are significantly different. 
b-Least-square means of the calving interval (CI) as affected by year and season of calving:

Table (7) showed that there is a highly significant difference in calving interval between the year of calving periods. It could be attributed to variation in management and environmental conditions. Similar results were also reported by Ayeneshet et al. (2018) in local cows in Ethiopia and Sanad and Hassane (2019) in crossbred Friesian cattle in Egypt and they explained that the difference could be due to the number of cows used and the emergence of new generations during the period of calving. Meanwhile, no significant effect of year of calving on CI was reported by Basak and Das (2018) of Deoni cattle in India.

The effect of season of calving was highly significant on CI. The longest CI was in the spring season 444 days (Table 7), it might be due to the cows calved in the spring season where inseminated in the summer season where the temperatures were high and there was a shortage in the available green folder, which led to a decrease in the reproductive efficiency of these cows compared to other seasons. The present finding was in agreement with that reported by Mekonnen et al (2011) on Horro cows in Ethiopia. Hermiz and Hadad (2020) reported that the cows calved in winter and spring had CI shorter than those calved in summer and autumn in Iraq. Conversely, Almasri (2010) reported that there was no significant effect of season of calving on CI of Holstein Friesian in Syria.

\section{c-Least-square means of the calving interval (CI) as affected by parity:}

The effect of parity on CI in the present study was significant. The calving interval was reduced with increased parities until the fourth parity (Table 7). It might be cows in early parities need high feeding requirements for growth, milk yield, and maintenance of life. This result agreed with that of Wondossen et al (2018) who indicated the shortest CI was in the third parity (443.4 days) and the longest in the first parity (492.9 days) in Holstein Friesian cows in Ethiopia.

On the contrary, Bahashwan (2020) indicated that the parity did not exert any significant effect on CI of Dhofari cows in the Sultanate of Oman.

\section{CONCLUSION}

The results showed Shami cows performed less efficiency in all studied traits compared to the Holstein cows under Syrian conditions. So, providing high quality management conditions and applying the best appropriate genetic improvement methods for Syrian Shami cows could result in conservation of local genetic resources and improving the economic traits.

\section{ACKNOWLEDGMENT}

The authors would like to thank the Institute of International Education's Scholar Rescue Fund (IIESRF) for funding publication of this research.

\section{REFERENCES}

Abera, M., 2016. Reproductive and Productive Performances of Crossbred and Indigenous Dairy Cattle under Rural, peri-urban and Urban Dairy Farming Systems in West Shoa Zone, Oromia, Ethiopia. M.Sc. Thesis. Jimma University College of Agriculture and Veterinary Medicine.

Alemayehu, T. and N. Moges, 2014. Study on Reproductive Performance of Indigenous Dairy Cows at Small Holder Farm Conditions in and Around Maksegnit Town. Global Veterinaria 13: 450-454.

Ali1,I., S. M. Suhail and M. Shafiq, 2019. Heritability estimates and genetic correlations of various production and reproductive traits of different grades of dairy cattle reared under subtropical condition. Reprod Dom Anim.54:1026-1033.

Almasri., O., 2010. Analysis Study for the Productive and Reproductive Traits of Holstein Friesian Cattle at Kharabo Dairy Farm.Master's thesis. Damascus University Syria.

Ansell, R.H., 1981. Extreme Heat Stress in Dairy Cattle and its Alleviation: A Case Report. In: Environmental Aspects of Housing for Animal Protection, Clark, J.A. (Ed.). Butterworths, London, UK.,pp: 285-306.

Ardicli, S., H. Samli, B. Soyudal, D. Dincel and F. Balci, 2019. Evaluation of candidate gene effects and environmental factors on reproductive performance of Holstein cows. South African Journal of Animal Science. 49 (2):380-394.

Ayeneshet, B., M. Abera and Z. Wondifraw, 2018. Reproductive and Productive Performance of Indigenous Dairy Cows under Smallholder Farmers Management System in North. J. Fisheries Livest Prod. 6 (1):2-5.

Azizunnesa, 2002. economic study of dairy the subsistence dairy farm in Mymensingh district. Bangladesh Agricultural University, Mymensingh.

Bahashwan, S., 2020. Dhofari cattle breed; productive and reproductive performance. Livestock Research for Rural. 32(2).

Basak, S. and D. Das, 2018. Effect of Parity, Period and Season of Calving on Production and Reproduction Traits on Deoni Cattle. Journal of Animal Health and Production. 6(1):1-4.

Bayou E., A. Haile, S. Gizaw and Y. Mekasha, 2015. Evaluation of non-genetic factors affecting calf growth, reproductive performance and milk yield of traditionally managed Sheko cattle in southwest Ethiopia. Springer plus. 40:865. 
Busato, A., P. Trachsel and J. W. Blum, 2000. Udder health and risk factors for subclinical mastitis in organic dairy farm in Switzerland. Prev. Vet. Med. 44:205-220.

Chaudhary, M. 1., M. Rafiq and M. A. Amar, 1996. Performance of various genetic groups of Holstein-Friesian crossbreeds. lih Ann. Report.(1995-96). Livestock Production Research Institute, Bahadurnagar, Okara (Pakistan).

Cherkoes, A. M. and Z. Mekuria, 2018. Factor Affecting Calving Interval of Dairy Cows in Central Highlands of Ethiopia. Journal of Biology, Agriculture and Healthcare. 8(3):71-76.

Cilek, S, 2009. Reproductive Traits of Holstein Cows Raised at Polatl State Farm in Turkey. J. Anim. Vet. $A d v \cdot 8(1): 1-5$.

Cilek, S. and G. Bakir, 2010. Milk Yield Traits of Brown Cows Reared at Malya State Farm and Effects of Some Environmental Factors on These Traits. KafkasUniv Vet FakDerg. 16(2):347-350.

Duplessis M, R. I. Cue, D. E. Santschi, D. M. Lefebvre and R. Lacroi, 2015. Weight, height, and relative-reliability indicators as a management tool for reducing age at first breeding and calving of dairy heifers. Journal of dairy science. 98: 2063-2073.

Ghoneim, E., S.ElKaschab, S. Omar and M.F. Omran, 2018. Comparative study among different dairy production system in Egypt. MenoufiaJ.Animal, Poultry \& fish Prod. 2:39:56.

Hermiz, H. N. and J. M. A. Hadad, 2020. Factors Affecting Reproductive Traits In Several Breeds Of Dairy Cattle In Iraq. Iraqi Journal of Agricultural Sciences. 51(2):629-636.

Kumar, D.K., C.E. Reddy, B.R. Gupta and A. Satyanarayana, 2003. Effect of year, season and lactation order on the performance of Ongole cattle. Indian J. Anim. Sci. 73(11): 1289-1290.

Kumar, J., Y. P. Singh, S. Kumar, R. Singh, R. Kumar and P. Kumar, 2015. Genetic analysis of reproductive performance of Frieswal cattle at Military Farm, Ambala. Veterinary World. 8:1032-1037.

Mamun, M.J.A., M.A.S. Khan, M.A.H. Sarker and M.N. Islam, 2015. Productive and reproductive performance of Holstein Friesian crossbred and indigenous cow under small holder farming system. Bang. J. Amin. Sci. 44(3): 166- 170.

Manzi, M., L. Rydhmer, M. Ntawubizi, C. D. Hirwa, C. Karege and E. Strandberg, 2020. Milk production and lactation length in Ankole cattle and Ankole crossbreds in Rwanda. Tropical Animal Health and Production. 52:2937-2943.

Mekonnen, A., A. Haile, T. Dessie and Y. Mekasha .2011.On Farm Evaluation of Growth and Reproductive Performance of Horro Cattle Breed in Western Oromia, Ethiopia.JAnim Feed Res.

Mekonnen., T. and M. Selam, 2020. Genetic Improvement Strategy of Indigenous Cattle Breeds: Effect of Cattle Crossbreeding Program on Their Reproductive Performances. Asian
Journal of Biotechnology and Genetic Engineering. 3(1): 19-30.

Mukasa-Mugerwa E, T.Azage, M. Tafese and Y. Taklu, 1991. Reproductive efficiency of Bosindicus (zebu) cows under artificial insemination. Animal Reproduction Science 24(12): 63-72.

Mulugeta, A. and A. Belayeneh, 2013. Reproductive and lactation performances of dairy cows in Chacha Town and nearby selected kebeles, North Shoa Zone, Amhara Region, Ethiopia, World Journal of Agricultural Sciences. 1(1): 008-

Pirlo, G., F. Miglior and M. Spironi, 2000. Effect of age at first calving on production traits and on difference between milk yield returns and rearing costs in Italian Holsteins. J. Anim. Sci. 83:603608.

Rojas-Downing, M.M., A. P. Nejadhashem, T. Harrigan and S. A. Woznicki, 2017. Climate change and livestock: impacts, adaptation, and mitigation. Climate Risk Management 16: 145163.

Sadek, R.R., E. A. Helali, M.A. Safwat, S.A.M. Ibrahim and A. Abd El-Fatah, 1994. Evaluation of Friesian cattle performance in commercial farms in Egypt. J.Anim.Prod. 31(1):43-64.

Saleem, M., I. Rahim, H. Rueff, M. Khan, D. Maselli, U. Wiesmann and S. Muhammad, 2012. Effect of management on reproductive performances of the Achai cattle in the Hindu Kush (Northern Pakistan). Trop Anim Health Prod. 44:1297-1302.

Sanad, S. S. and M. S. Hassane, 2019. Genetic Factors Affecting Total Milk Yield, Lactation Period And Calving Interval Of Crossbred Friesian Cows Raised On Nile Delta. Egypt. J. Agric. Res., 97 (2):771-784.

Sattar, A., R. H. Mirza, A. A. K. Niazi and M. Latif, 2005. Productive and reproductive performance of Holstein Friesian cows in pakistan. Pakistan Vet. J .25(2):75-81.

Sawa, A., K. Siatka and S. Krężel-Czopek, 2019. Effect of age at first calving on first lactation milk yield, lifetime milk production and longevity of cows, Annals of Animal Science, DOI: 10.2478/aoas-2018-0044.

Tadesse, M. and T. Dessie, 2003. Milk production performance of Zebu, Holstein Friesian and their crosses in Ethiopia. Livestock Research for Rural Development (15) 3.

Toure, A., N. Antoine-Moussiaux, F. Geda, A. Kouriba, D. Traoré, B. Traore, P. Leroy and N. Moula, 2019. Phenotypic parameters affecting reproduction and production performances of dairy cattle in peri-urban of Bamako, Mali. Veterinary World.817-822.

Wondossen, A., A. Mohammed and E. Negussie, 2018. Reproductive Performance of Holstein Friesian Dairy Cows in a Tropical Highland Environment. J. Adv Dairy Res. 6(2):2-6. 


\section{توصيف بعض الصفات الإنتاجية والتناسلية للأبقار الثامية السورية وأبقار الهولثتاين تحت الظروف السورية

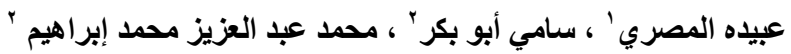

ا - إدارة بحوث الثروة الحيوانية، الهيئة العامة للبحوث العلمية الزراعية، سورية، r ـ قسم الإنتاج الحيواني، كلية الزراعة، جامعة القاهرة،

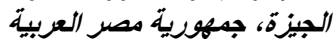

هدفت هذه الدراسة إلى توصيف الأداء الإنتاجي والتناسلي للأبقار الثامية السورية وأبقار الهولثنتاين تحت الظروف السورية. في هذه

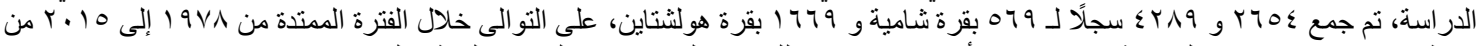

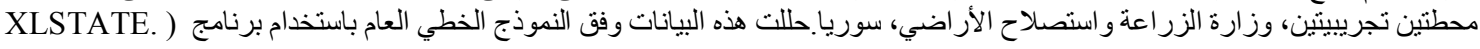
تأثر كلاً من العمر عند أول و لادة (AFC) والفترة بين الولادتين (CI) و إنتاج اللبن الكلي (TMY) وإنتاج اللبن اليومي (DMY) وطول

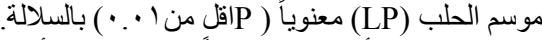

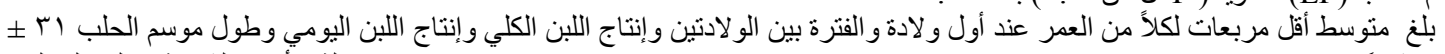

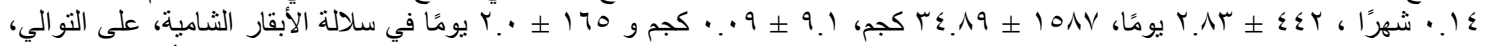

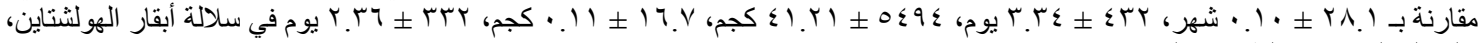

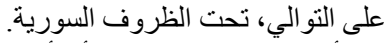

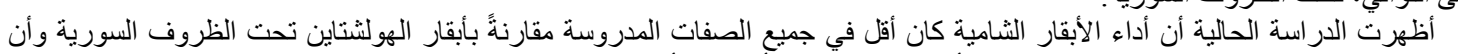
تحسين ظروف الرعاية وإجراء التحسين الور اني للأبقار الثامية يمكن أن يعزز أدائها الإنتاجي والتناسلي. 